\title{
LITERATURE REVIEW MANFAAT SENAM LANSIA TERHADAP KUALITAS HIDUP LANSIA
} Sri Puzzy Handayani ${ }^{1}$, Rina Puspita Sari², Wibisono ${ }^{2}$

${ }^{1}$ Mahasiswa Program S1 Keperawatan STIKes Yatsi Tangerang 15113, Indonesia

2Dosen Keperawatan STIKes Yatsi Tangerang 15113, Indonesia

\begin{abstract}
ABSTRAK
Pendahuluan: Jumlah keluhan kesehatan pada lansia perempuan lebih tinggi dibandingkan dengan lansia laki-laki. Perubahan yang terjadi pada lansia cenderung akan mengalami penurunan pada fisik, sistem psikologis, psikososial. Hal ini membutuhkan suatu tindakan aktivitas yang dapat menjangkau seluruh aspek yang mengalami penurunan tersebut yaitu dengan melakukan senam lansia.

Penelitian ini bertujuan: Untuk mengidentifikasi manfaat senam lansia terhadap kualitas hidup lansia.

Metode Penelitian: Dengan menggunakan literature review sebagai panduan pencarian artikel penelitian diperoleh dari internet menggunakan situs Science Direct, dan Google Scholar.

Hasil: Analisis dari 10 artikel penelitian yang terpilih menunjukan bahwa senam lansia dapat memiliki beberapa manfaat yaitu : manfaat pada fisik dapat meningkatkan kebugaran jasmani, keseimbangan tubuh, pernafasan, dan penurunan tekanan darah pada lansia hipertensi. Manfaat pada psikologis dapat memperbaiki kualitas tidur, penurunan tingkat insomnia, penurunan tingkat depresi, penurunan tingkat stres, dan manajemem nyeri. Manfaat sosial dan lingkungan.

Kesimpulan: Hasil dari literature review ini bahwa senam lansia dapat memiliki beberapa manfaat yaitu : manfaat pada fisik dapat meningkatkan kebugaran jasmani, keseimbangan tubuh, pernafasan, dan penurunan tekanan darah pada lansia hipertensi. Manfaat pada psikologis dapat memperbaiki kualitas tidur, penurunan tingkat insomnia, penurunan tingkat depresi, penurunan tingkat stres, dan manajemen nyeri serta manfaat sosial dan lingkungan. Melakukan senam lansia 3 kali dalam seminggu dengan durasi minimal 30 menit dan maksimal 40 menit dengan waktu >4 minggu akan lebih efektif mendapatkan banyak manfaatnya kualitas hidup lansiapun akan mengalami peningkatan.
\end{abstract}

\section{Kata Kunci: Senam Lansia, Kualitas Hidup, Lansia}

\begin{abstract}
Introduction: The number of health complaints in elderly women is higher than that of male elderly. Changes that occur in the elderly tend to decrease in physical, psychological, psychosocial systems. This requires an action activity that can reach all aspects of the decline that is by doing elderly gymnastics.

The purpose of this research to identify the benefits of elderly exercise on the quality of life of the elderly.

Research methods by using literature review as a guide to search for research articles obtained from the internet using the Science Direct site, and Google Scholar.

The results analysis of 10 selected research articles shows that elderly exercise can have several benefits, namely: physical benefits can improve physical fitness, body balance, breathing, and decreased blood pressure in elderly hypertension. Psychological benefits can improve sleep quality, decrease insomnia levels, decrease depression levels, reduce stress levels, and manage pain. Social and environmental benefits.

Conclusion: The results of this literature review show that exercise in the elderly can have several benefits, namely: physical benefits can improve physical fitness, body balance, respiration, and decrease blood pressure in hypertensive elderly. The
\end{abstract}


psychological benefits can improve sleep quality, decrease insomnia rates, decrease depression levels, reduce stress levels, and manage pain as well as social and environmental benefits. Doing gymnastics for the elderly 3 times a week with a duration of at least 30 minutes and a maximum of 40 minutes with a time of $>4$ weeks will be more effective in getting many benefits, the quality of life of the elderly will increase.

\section{Keywords: Elderly Gymnastics, Quality of Life, Elderly}

\section{PENDAHULUAN}

Lansia merupakan tahap terakhir proses perjalanan dalam kehidupan manusia sejak lahir sampai mencapai usianya lebih dari 60 tahun. Lansia secara keseluruhan akan mengalami penurunan biologis. Menurunnya masa tulang dan masa otot sehingga akan menyebabkan terjadinya penurunan keseimbangan yang sangat beresiko terhadap kejadian jatuh pada lansia. [11]

Populasi usia lanjut dalam perkembangannya selalu mengalami peningkatan. Proporsi penduduk lansia yang berumur lebih dari 60 tahun mencapai satu juta orang . sekitar $80 \%$ dari lansia tersebut berasal dari Negara berkembang dan estimasi Perserikatan Bangsa Bangsa (PBB) dunia akan berlipat ganda dari 600 juta menjadi 1,2 miliar pada 2025 dan akan menjadi dua miliar pada tahun 2050.. ${ }^{[14]}$ Indonesia diperkirakaan akan mengalami "elderly population boom" pada 2 dekade awal abad ke-21 sebagai dampak dari baby boom pada beberapa puluh tahun yang lalu. BPS memproyeksikan pada tahun 2045 Indonesia akan memiliki sekitar 63,31 juta lansia atau hampir mencapai dengan $20 \%$ populasi. Bahkan proyeksi PBB menyebutkan persentase lansia Indonesia akan mencapai $25 \%$ pada tahun 2050 atau sekitar 74 juta lansia. Presentase lansia akan terus meningkat seiringnya bertambah waktu."PBB memprediksi bahwa pada tahun 2030 jumlah lansia akan melebihi jumlah anak dibawah 10 tahun $(1,41$ miliar berbanding 1,35 miliar). Proyeksi di tahun 2050 mengindikasikan bahwa akan lebih banyak usia 60 tahun keatas dibandingkan dengan usia remaja dan pemuda berusia 10 tahun ke atas sampai usia 24 tahun yaitu sekitar 2,1 miliar berbanding dengan 2 miliar di seluruh dunia". [2]

Menjadi tua semua orang akan mengalami karena disebabkan semakin bertambahnya usia maka akan ditandai dengan adanya perbuhan anatomis dan fisiologis yaitu merupakan proses menua dan akan menyebabkan penurunan kualitas hidup sehingga status lansia dalam kondisi sehat sakit. Selain itu kualitas hidup yang kurang baik biasanya dapat dilihat berkurangnya kesehatan fisik, kesehatan psikologi, hubungan sosial dan aspek lingkungan. ${ }^{[7]}$ Fungsi organ dalam tubuh akan mengalami penurunan akibat terjadinya proses menua. Lansia cenderung akan mengalami penurunan pada fisik, sistem psikologis, psikososial yang dialami lansia berhubungan dengan keterbatasan kegiatan kerjanya, dan perubahan kognitif. Penurunan pada sistem psikologis ini dapat mempengaruhi daya ingat yang menurun, kewaspadaan yang meningkat, berkurangnya gairah seksual, dan perubahan pola tidur (gangguan tidur). ${ }^{[8]}$

Semakin bertambahnya usia , presentase penduduk lansia mengalami keluhan kesehatan semakin meningkat seiring dengan bertambahnya usia. Jumlah keluhan kesehatan di Indonesia pada lansia perempuan $52,31 \%$ lebih tinggi dibandingkan persentasi dengan lansia laki-laki yaitu 49, 74\%. Jumlah keluhan kesehatan selama sebulan terakhir di provinsi Banten 51,90\% bagian kota, $62,52 \%$ di daerah, 52,17 pada lansia laki-laki, dan $58,99 \%$ pada lansia perempuan (Badan Pusat Statistik, 2019). Terdapat $64,58 \%$ lansia dengan kualitas hidup yang kurang, $61,1 \%$ dengan aktivitas sosial yang kurang, dan 52,8\% lansia dengan interaksi yang kurang. ${ }^{[10]}$

Salah satu upaya untuk mempertahankan kesehatan pada lansia itu sendiri dari pola hidup yang sehat salah satunya dengan olahraga yang bisa dilakukan oleh siapa saja terutama pada lansia juga bisa melakukannya. Senam lansia adalah salah satu aktivitas 
olahraga yang bisa dilakukan pada usia lanjut, melakukan kegiatan olahraga ini sangat dapat membantu tubuh usia lanjut untuk menjaga kebugaran tubuh karena dapat membantu untuk menghilangkan radikal bebas yang berada di dalam tubuh. ${ }^{[15]}$

Berdasarkan hasil penelitian yang dilakukan Tabita Ma Windri, dkk (2019) didapatkan bahwa sebelum dilakukan aktivitas fisik rata-rata kualitas hidup $62,8 \%$ dan meningkat menjadi $65.25 \%$. dari domain kualitas hidup ini dibagi menjadi 4 yaitu kesehatan fisik, kesehatan jiwa, hubungan sosial, dan lingkungan. Dapat disimpulkan terdapat kenaikan kualitas hidup lansia dengan rata-rata $2,48 \%$.

Berdasarkan uraian diatas peneliti tertarik untuk melihat lebih dalam beberapa literatur terkait manfaat senam lansia bagi kesehatan lansia. Tujuan kajian pustaka ini adalah untuk mengetahui berbagai manfaat kesehatan yang diberikan senam lansia sehingga nantinya dapat dijadikan rekomendasi untuk intervensi modalitas yang terapeutik untuk lansia.

\section{LITERATURE REVIEW}

literature review yang didefinisikan sebagai suatu pengumpulan data dan informasi dengan metode menggali pengetahuan atau ilmu dari berbagai sumber seperti buku, karya tulis diktat catatan kuliah, jurnal, serta beberapa sumber lainnya yang ada hubungannya dengan objek penelitian untuk menghasilkan suatu pemikiran baru dengan satu topik atau permasalahan tertentu dalam kajian literature yang dapat menghasilkan sebuah tulisan ilmiah. ${ }^{[9]}$

\section{METODOLOGI PENELITIAN}

Sumber literature review ini disusun yang diawali dengan pemilihan topik kemudian sumber dari studi ini diambil dari pencarian dari buku, beberapa artikel dan jurnal yang telah dipublikasi. Penelusuran pada studi ini diperoleh dari internet menggunakan situs Science Direct, dan Google Scholar yang menggunakan keyword "manfaat" "senam lansia" "untuk" "kualitas hidup lansia" dan keyword dalam bahasa inggris "benefits" "elderly exercise" "for" "the quality of life of the elderly".

Pencarian kelayakan artikel dan artikel yang terpilih untuk tinjauan dalam penelitian ini diringkas dalam bagan dibawah ini, dilakukan secara sistematis dengan mengikuti tahapan yang benar dengan menggunakan format PRISMA. ${ }^{[13]}$

1. Bagan Format PRISMA

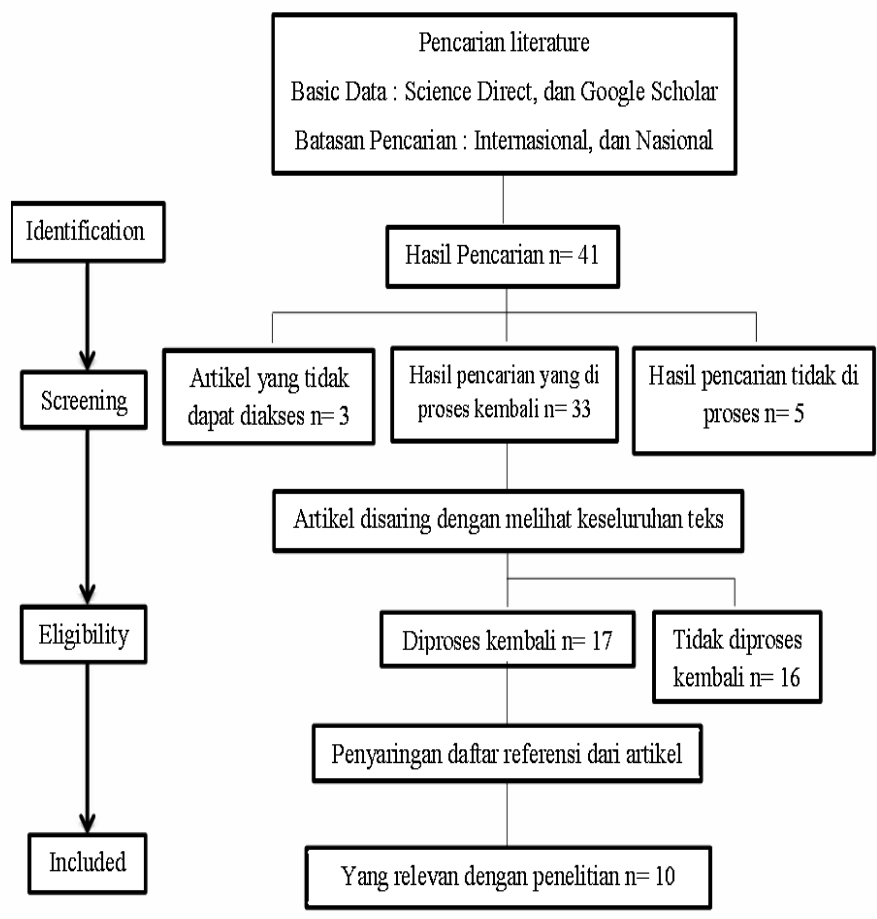

HASIL

Dari 10 artikel yang terpilih terdiri dari tahun 2016-2020, 1 jurnal internasional dan 9 jurnal nasional. Artikel-artikel yang terpilih dari negara Indonesia dan Afrika. Domain kualitas hidup ini dibagi menjadi 4 yaitu kesehatan fisik, kesehatan jiwa, hubungan sosial, dan lingkungan. Dari beberapa artikel yang terpilih tema yang didapatkan dari kajian pustaka ini adalah manfaat yang dirasakan oleh lansia setelah dilakukannya senam lansia yaitu : Manfaat fisik : Kebugaran jasmani, keseimbangan tubuh, pernafasan, dan penurunan tekanan darah pada lansia hipertensi. Manfaat pada psikologis dapat memperbaiki kualitas tidur, penurunan tingkat insomnia, penurunan 
tingkat depresi, penurunan tingkat stres,

dan manajemem nyeri. Manfaat sosial dan lingkungan.

Tabel 1. Hasil Penelitian Artikel Terpilih

\begin{tabular}{|c|c|c|c|c|c|}
\hline No & Peneliti & Sampel & Judul & Sumber & Hasil/Kesimpulan \\
\hline 1 & $\begin{array}{l}\text { Resmi } \\
\text { Pangaribu } \\
\text { an, Nina } \\
\text { Olivia }\end{array}$ & 15 lansia & $\begin{array}{l}\text { Senam Lansia } \\
\text { Pada Reumatoid } \\
\text { Arthtitis Dengan } \\
\text { Nyeri Lutut Di } \\
\text { Upt Pelayanan } \\
\text { Sosial Lanjut } \\
\text { Usia Binjai }\end{array}$ & $\begin{array}{l}\text { Indonesian Trust } \\
\text { Health Journal } \\
\text { Volume 3, No, } 1 \\
\text { April } 2020 \\
\text { Cetak ISSN : } \\
2620-5564 \\
\text { Online ISSN : } \\
\text { 2655-1292 } \\
\text { http://jurnal.stikes- } \\
\text { murniteguh.ac.id/i } \\
\text { ndex.php/ithj/articl } \\
\text { e/view/46 }\end{array}$ & $\begin{array}{l}\text { Hasil penelitian } \\
\text { menunjukan bahwa } \\
\text { adanya penurunan } \\
\text { skala nyeri pada } \\
\text { kasus rematoid } \\
\text { arthtristis hal ini } \\
\text { dibuktikan nilai uji } \\
\text { statistik di dapatkan } \\
\text { nilai } p \text { value } 0,001 \\
\text { yang berarti sig < a } \\
=(0,05) \text {. Nilai } \\
\text { signifikasi } 0,001< \\
0,05 \text {. }\end{array}$ \\
\hline 2 & $\begin{array}{l}\text { Ernauli } \\
\text { meliyana, } \\
\text { dan siti } \\
\text { maria ulfa }\end{array}$ & $\begin{array}{l}20 \\
\text { responden }\end{array}$ & $\begin{array}{l}\text { Pengaruh } \\
\text { senam lansia } \\
\text { terhadap tingkat } \\
\text { insomnia pada } \\
\text { lansia di } \\
\text { yayasan bina } \\
\text { bhakti sasana } \\
\text { tresnawherda } \\
\text { caritas bekasi }\end{array}$ & $\begin{array}{l}\text { Manuju : } \\
\text { Malahayati } \\
\text { Nursing Journal } \\
\text { Volume 1, Nomor } \\
\text { 1 Januari } 2019 \\
\text { P-ISSN : } \\
\text { 2655-2728 } \\
\text { E-ISSN : } \\
2655-4712 \\
\text { https://core.ac.uk/ } \\
\text { download/pdf/237 } \\
\text { 009278.pdf }\end{array}$ & $\begin{array}{l}\text { Hasil dalam } \\
\text { penelitian ini } \\
\text { terdapat ada } \\
\text { perbedan yang } \\
\text { signifikan antara } \\
\text { senam lansia } \\
\text { terhadap tingkat } \\
\text { insomnia pada } \\
\text { lansia dengan hasil } \\
\text { uji statistik } p \text { value } \\
0,000<0,05 \text {. }\end{array}$ \\
\hline 3 & Nur Iffah & 26 orang & $\begin{array}{l}\text { Pengaruh } \\
\text { Senam } \\
\text { Terhadap } \\
\text { Penurunan } \\
\text { Depresi Pada } \\
\text { Lansia Di } \\
\text { Posyandu Ke. } \\
\text { Madyopuro, } \\
\text { Kec. } \\
\text { Keungkandang } \\
\text { Malang }\end{array}$ & $\begin{array}{l}\text { Jurnal } \\
\text { Conference on } \\
\text { Research \& } \\
\text { Community } \\
\text { Services 2019 } \\
\text { ISSN 2686-1259 } \\
\text { https://core.ac.uk/ } \\
\text { download/pdf/267 } \\
\text { 901733.pdf }\end{array}$ & $\begin{array}{l}\text { Hasil dalam } \\
\text { penelitian ini } \\
\text { terdapat pengaruh } \\
\text { senam lansia } \\
\text { terhadap } \\
\text { penurunan depresi } \\
\text { pada lansia dengan } \\
\text { hasil uji statistik. }\end{array}$ \\
\hline 4 & $\begin{array}{l}\text { Ropika } \\
\text { Ningsih }\end{array}$ & 20 orang & $\begin{array}{l}\text { Efektivitas } \\
\text { Pemberian } \\
\text { Senam Lanjut } \\
\text { Usia Terhadap } \\
\text { Penurunan } \\
\text { Tingkat Stres } \\
\text { Usia Lanjut Di } \\
\text { Panti Sosial } \\
\text { Tresna Werdha }\end{array}$ & $\begin{array}{l}\text { Jurnal MENARA } \\
\text { IImu Vol. XIII No. } \\
3 \text { Januari } 2019 \\
\text { ISSN : 1693-2617 } \\
\text { E-ISSN : } \\
2528-7613 \\
\text { https://www.jurnal } \\
\text { umsb.ac.id/index. } \\
\text { php/menarailmu/a } \\
\text { rticle/viewFile/122 } \\
\text { 7/1079 }\end{array}$ & $\begin{array}{l}\text { Hasil dalam } \\
\text { penelitian ini } \\
\text { terdapat penurunan } \\
\text { stres setelah } \\
\text { dilakukan senam } \\
\text { lanjut usia dengan } \\
\text { hasil uji T-test } p \\
\text { value } 0,008<0,05\end{array}$ \\
\hline 5 & $\begin{array}{l}\text { Edo } \\
\text { Fralian }\end{array}$ & 72 lansia & $\begin{array}{l}\text { Model Senam } \\
\text { Lansia Untuk }\end{array}$ & $\begin{array}{l}\text { Jurnal } \\
\text { Keolahragaan, }\end{array}$ & $\begin{array}{l}\text { Hasil dalam } \\
\text { penelitian ini }\end{array}$ \\
\hline
\end{tabular}




\begin{tabular}{|c|c|c|c|c|c|}
\hline & $\begin{array}{l}\text { Putra, dan } \\
\text { S. } \\
\text { Suharjana }\end{array}$ & & $\begin{array}{l}\text { Kebugaran } \\
\text { Jasmani dan } \\
\text { Fungsi Otak }\end{array}$ & $\begin{array}{l}\text { Vol. } 6 \text { No. } 2 \\
2018 \\
\text { ISSN 2339-0662 } \\
\text { (print) } \\
\text { ISSN 2461-0259 } \\
\text { (online) } \\
\text { https://journal.uny } \\
\text { ac.id/index.php/jo } \\
\text { lahraga/article/vie } \\
\text { w/20626 }\end{array}$ & $\begin{array}{l}\text { menunjukkan } \\
\text { senam lansia dapat } \\
\text { pengaruh } \\
\text { memberikan } \\
\text { keseimbangan dan } \\
\text { fungsi kognitif pada } \\
\text { lansia }\end{array}$ \\
\hline 6 & $\begin{array}{l}\text { Kaimuddi } \\
\mathrm{n} \text { dan Cek } \\
\text { Masnah }\end{array}$ & $\begin{array}{l}\text { Semua } \\
\text { lansia yang } \\
\text { mengikuti } \\
\text { senam } \\
\text { lansia }\end{array}$ & $\begin{array}{l}\text { Efektifitas } \\
\text { Senam } \\
\text { Terhadap } \\
\text { Pernafasan } \\
\text { Lansia di } \\
\text { Wilayah } \\
\text { Puskesmas } \\
\text { Simpang Kawat } \\
\text { Kota Jambi }\end{array}$ & $\begin{array}{l}\text { Jurnal Bahan } \\
\text { Kesehatan } \\
\text { Masyarakat Vol. } 2 \\
\text { No. } 2 \\
2018 \\
\text { p-ISSN : } \\
\text { 2085-1677 } \\
\text { e-ISSN : } \\
\text { 2621-3801 } \\
\text { http://www.journal } \\
\text { poltekkesjambi.a } \\
\text { c.id/index.php/JB } \\
\text { KM/article/view/12 } \\
\underline{3}\end{array}$ & $\begin{array}{l}\text { Hasil dalam } \\
\text { penelitian } \\
\text { menunjukan bahwa } \\
\text { terdapat ada } \\
\text { perbedaan diantara } \\
\text { dua kelompok dan } \\
\text { terbukti bahwa } \\
\text { senam lansia dapat } \\
\text { meningkatkan } \\
\text { kekuatan otot } \\
\text { pernafasan dan } \\
\text { fungsi otot paru } \\
\text { pada lansia. }\end{array}$ \\
\hline 7 & $\begin{array}{l}\text { Knajihah, } \\
\text { dan } \\
\text { Rahmawa } \\
\text { ti Ramli }\end{array}$ & 14 lansia & $\begin{array}{l}\text { Senam Lansia } \\
\text { Menurunkan } \\
\text { Tekanan Darah } \\
\text { Pada Lansia } \\
\text { Hipertensi }\end{array}$ & $\begin{array}{l}\text { Window of Health, } \\
\text { Vol. } 1 \text { No. } 1 \\
\text { Januari } 2018 \\
\text { E-ISSN } \\
2614-5375 \\
\text { http://jurnal.fkmu } \\
\text { mi.ac.id/index.php } \\
\text { woh/article/view/ } \\
\text { woh1102 }\end{array}$ & $\begin{array}{l}\text { Hasil dalam } \\
\text { penelitian ini } \\
\text { menunjukan bahwa } \\
\text { senam lansia dapat } \\
\text { menurunkan } \\
\text { tekanan darah } \\
\text { pada lansia yang } \\
\text { mengalami } \\
\text { hipertensi dengan } \\
\text { hasil uji T test } p \\
\text { value } 0,02<0,05\end{array}$ \\
\hline 8 & Nislawaty & 24 lansia & $\begin{array}{l}\text { Pengaruh } \\
\text { Senam Lansia } \\
\text { Terhadap } \\
\text { Kualitas Tidur } \\
\text { Pada Lansia Di } \\
\text { Pelayanan } \\
\text { Sosial Tresna } \\
\text { Werdha Khusnul } \\
\text { Khotimah } \\
\text { Kelurahan } \\
\text { Simpang Tiga } \\
\text { Pekanbaru } \\
\text { Tahun } 2016\end{array}$ & $\begin{array}{l}\text { OREPOTIF Jurnal } \\
\text { Kesehatan } \\
\text { Masyarakat } \\
\text { Volume 1, Nomor } \\
\text { 1 April 2017 } \\
\text { ISSN 2623-1573 } \\
\text { (Online) } \\
\text { ISSN 2623-1581 } \\
\text { (Print) } \\
\text { http://journal.univ } \\
\text { ersitaspahlawan.a } \\
\text { c.id/index.php/pre } \\
\text { potif/article/view/1 } \\
4\end{array}$ & $\begin{array}{l}\text { Hasil dalam } \\
\text { penelitian ini } \\
\text { terdapat pengaruh } \\
\text { senam lansia } \\
\text { terhadap kualitas } \\
\text { tidur pada lansia. } \\
\text { Hal ini dibuktikan } \\
\text { bahwa nilai } p \text { value } \\
0,000 \leq \text { ą }=0,05\end{array}$ \\
\hline 9 & $\begin{array}{l}\text { Nivash } \\
\text { Rugbeer, } \\
\text { Serela } \\
\text { Ramklass } \\
\text {, Andrew } \\
\text { Mckune, }\end{array}$ & 84 orang & $\begin{array}{l}\text { The effect of } \\
\text { group exercise } \\
\text { frequency on } \\
\text { health related } \\
\text { quality } \\
\text { of life in }\end{array}$ & $\begin{array}{l}\text { Pan African } \\
\text { Medical Journal - } \\
\text { ISSN: 1937- } 8688 \\
\text { (www.panafrican- } \\
\text { med-journal.com) } \\
\text { Published in }\end{array}$ & $\begin{array}{l}\text { Hasil dalam } \\
\text { penelitian ini } \\
\text { terdapat perbedaan } \\
\text { yang signifikan } \\
\text { dalam fungsi } \\
\text { soasial, vitalitas }\end{array}$ \\
\hline
\end{tabular}




\begin{tabular}{|c|c|c|c|c|c|}
\hline & $\begin{array}{l}\text { Johan van } \\
\text { Heerden }\end{array}$ & & $\begin{array}{l}\text { institutionalized } \\
\text { elderly }\end{array}$ & $\begin{array}{l}\text { partnership with } \\
\text { the African Field } \\
\text { Epidemiology } \\
\text { Network } \\
\text { (AFENET). } \\
\text { (www.afenet.net) } \\
2017\end{array}$ & $\begin{array}{l}\text { dan kesehatan } \\
\text { mental }\end{array}$ \\
\hline 10 & $\begin{array}{l}\text { Meril } \\
\text { Valentine } \\
\text { Manangk } \\
\text { ot, I } \\
\text { Wayan } \\
\text { Sukawan } \\
\text { a, I Made } \\
\text { Surata } \\
\text { Witarsa }\end{array}$ & 27 orang & $\begin{array}{l}\text { Pengaruh } \\
\text { Senam Lansia } \\
\text { Terhadap } \\
\text { Keseimbangan } \\
\text { Tubuh Pada } \\
\text { Lansia Di } \\
\text { Lingkungan } \\
\text { Dajan Bingin } \\
\text { Sading }\end{array}$ & $\begin{array}{l}\text { Jurnal } \\
\text { Keperawatan } \\
\text { Community Of } \\
\text { Publishing In } \\
\text { Nursing } \\
\text { (COPING) NERS } \\
\text { Januari-April } 2016 \\
\text { ISSN : } 2303-1298 \\
\text { https://ojs.unud.ac } \\
\text {.id/index.php/copi } \\
\text { ng/article/downloa } \\
\text { d/19909/13223 }\end{array}$ & $\begin{array}{l}\text { Hasil dalam } \\
\text { penelitian ini } \\
\text { terbukti bahwa hasil } \\
T \text { Test Paried } 0,001 \\
\text { maka } \mathrm{p} \leq 0,05 \text { yang } \\
\text { berarti ada } \\
\text { pengaruh senam } \\
\text { lansia terhadap } \\
\text { keseimbangan } \\
\text { tubuh lansia }\end{array}$ \\
\hline
\end{tabular}

\section{DISKUSI}

Lansia adalah bukan suatu penyakit, tetapi tahap lanjut dari suatu proses kehidupan yang ditandai dengan penurunan kemampuan tubuh untuk beradaptasi dengan stres lingkungan. Penurunan kemampuan berbagai organ, fungsi, dan sistem tubuh itu bersifat alamiah atau fisiologis. Penurunan tersebut disebabkan berkurangnya jumlah dan kemampuan sel tubuh. Pada umumnya tanda yang terjadi pada proses menua mulai tampak saat usia 45 tahun dan akan menimbulkan masalah pada usia sekitar 60 tahun.

Senam lansia dapat menjadi intervensi yang dapat meningkatkan aspek-aspek kualitas hidup lansia sesuai dengan hasil artikel-artikel penelitian yang sudah dipilih. Senam lansia adalah serangkaian gerakan yang tearah dan teratur kemudian diikuti oleh para lansia yang pelaksanaanya dimaksudkan untuk meningkatkan kemampuan raga secara fungsional. ${ }^{[6]}$

Melakukan senam lansia dapat menjadi intervensi yang dapat meningkatkan kualitas hidup sesuai dengan hasil telaah kajian artikel-artikel penelitian terpilih. Hasil dari penelitian Kowel, dkk (2016) menjelaskan dalam penelitian ini terdapat hal positif yang dirasakan lansia setelah senam lansia bahwa responden mengalami peningkatan kebugaran tubuh, nafsu makan meningkat, peningkatan mobilitas, kualitas pernafasan meningkat, derajat kelelahan otot mengalami penurunan, menghilangkan nyeri bahu kronis, keinginan kerja meningkat, dan mengalami perubahan positif pada ADL. Hasil dari penelitian Nur Iffah (2019) menjelaskan Setelah dilakukan senam terlihat perkembangan yang didapatkan pada lansia seperti bisa bersosialisasi dalam senam, bisa lebih banyak berkomunikasi, ada perubahan prilaku dimana lansia mulai sering bertegur sapa, dan bercanda. Senam ini dapat meningkatkan interaksi karena komunikasi.

Kekurangan dari beberapa jurnal tidak membahas manfaat untuk yang lainnya, dan ada 4 jurnal yang membahas manfaat lain selain pembahasan yang diambil. Dalam 1 jurnal tidak menjelaskan secara detail terkait berapa jumlah yang menjadi responden tetapi hanya menunjukkan lansia yang mengikuti senam dan 1 jurnal tidak menjelaskan secara detail terkait data hasil sebelum perlakuan. Sebagian besar dalam jurnal melakukan penelitian dengan desain one group pre test-post test sehingga hasil hanya dapat melihat dari 1 kelompok tanpa bisa membandingkan dengan kelompok kontrol. Kelebihan dari semua jurnal dapat disimpulkan bahwa senam lansia dapat memberikan manfaat pengaruh 
terhadap lansia pada kesehatan fisik bisa memberikan kebugaran jasmani, keseimbangan tubuh, pernafasan, penurunan tekanan darah. Pada psikologis dapat memberikan efek kualitas tidur membaik, penurunan tingkat insomnia, penurunan tingkat depresi, penurunan tingkat stres, dan untuk mengurangi rasa nyeri serta memberikan manfaat pada sosial dan lingkungan.

Dalam melakukan senam lansia ada 3 fase yang harus dilakukan yaitu pemanasan, gerakan inti, dan pendinginan. [1] Masing-masing jurnal membahas tentang pengaruh dan perbandingan dengan senam lansia terdapat kekurangan dalam cara perlakuan dari setiap jurnal tidak membahas bagaimana cara pelaksanaanya hanya terdapat 1 jurnal yang membahasnya. 6 jurnal tidak membahas tentang lama dan durasi perlakuan senam pada lansia. Sebagian jurnal tidak mencantumkan sesuai teori berapa kali dalam seminggu, lama durasi dan dilakukan berapa minggu/bulan sedangkan menurut Kemenkes (2018) aktifitas fisik dapat dilakukan minimal 30 menit/hari selama $5 x /$ minggu, boleh dilakukan sebanyak $3 x$ sehari selama 10 menit atau $2 x$ sehari selama 15 menit. Bagi yang mempunyai masalah dalam tubuh seperti kolestrol dan tekanan darah, dianjurkan untuk melakukan minimal 40 menit Latihan dengan intensitas sedang sebanyak 3-4x/ minggu. Kelebihan dari semua jurnal ini dapat memberikan pengaruh yang efektif untuk memberikan manfaat terhadap lansia Dapat disimpulkan dengan melakukan senam lansia 3 kali dalam seminggu dengan durasi minimal 30 menit dan maksimal 40 menit dengan waktu >4 minggu akan lebih efektif mendapatkan banyak manfaatnya. Diharapkan untuk para lansia dapat melakukan senam lansia secara rutin agar mendapatkan hasil yang optimal sehingga meningkatkan kualitas hidup lansia.

Implikasi literature ini bagi bidang keperawwatan gerontik adalah perawat dapat mengintegrasikan senam lansia sebagai salah satu terapi aktivitas kelompok bagi lansia dalam asuhan keperawatan. Senam lansia bukan hanya bermanfaat untuk kebugaran tubuh saja, tetapi juga bagi kesehatan fisik, psiklogis, sosial dan lingkungan aka meningkatkan kemampuan potensial lansia dalam menjalani hidupnya yang merupakan tujuan utama dalam perawatan lansia.

\section{KESIMPULAN DAN SARAN}

Hasil dari literature review ini bahwa senam lansia dapat memiliki beberapa manfaat yaitu : manfaat pada fisik dapat meningkatkan kebugaran jasmani, keseimbangan tubuh, pernafasan, dan penurunan tekanan darah pada lansia hipertensi. Manfaat pada psikologis dapat memperbaiki kualitas tidur, penurunan tingkat insomnia, penurunan tingkat depresi, penurunan tingkat stres, dan manajemem nyeri. Manfaat sosial dan lingkungan, serta manfaat fungsi kognitif dapat meningkatkan kognitif. Dengan melakukan senam lansia 3 kali dalam seminggu dengan durasi minimal 30 menit dan maksimal 40 menit dengan waktu >4 minggu akan lebih efektif mendapatkan banyak manfaatnya kualitas hidup lansiapun akan mengalami peningkatan.

\section{Saran Bagi Peneliti Selanjutnya}

Peneliti selanjutnya dapat menjadikan hasil karya literature review ini sebagai bahan acuan untuk melakukan penelitian selanjutnya, dengan konstruk yang sama namun dengan objek berbeda. Atau dapat membandingkan faktor-faktor lain yang mempengaruhi.

\section{UCAPAN TERIMAKASIH}

Peneliti mengucapkan terimakasih kepada pembimbing yang telah membantu dan memotivasi dalam literature review ini. Selain itu pada keluarga dan teman-teman yang selalu memberikan semangat.

\section{DAFTAR PUSTAKA}

1. Adiputra, Nyoman Et Al. 2016. "Perbandingan Kombinasi Bergantian Senam Lansia Dan Latihan Core Stability The Comparison Of Turn Combination Of Elderly Gymnastic 
And Core Stability Exercise With Elderly Gymnastic Only To Increase." Sport And Fitness Journal 4(1): 1-15.

2. Badan Pusat Statistik. 2018. Statistik Penduduk Lanjut Usia 2018. Jakarta: Badan Pusat Statistik.

3. Badan Pusat Statistik. 2019. Statistik Penduduk Lanjut Usia 2019. Jakarta.

4. Iffah, Nur. 2020. "Pengaruh Senam Terhadap Penurunan Depresi Pada Lansia Di Posyandu Kel. Madyopuro, Kec. Keungkandang Malang." Conference On Research \& Community Services: 433-41.

5. Kowel, Richard, Herlina I S Wungouw, And Vanda D Doda. 2016. "Pengaruh Senam Lansia Terhadap Derajat Depresi Pada Lansia Di Panti Werda." Jurnal E-Biomedik (Ebm) 4.

6. Mardius, Ali, And Yuni Astuti. 2018. "Pengaruh Senam Lansia Terhadap Kebugaran Jasmani Warga Perumahan Pondok Pinang Kelurahan Lubuk Buaya Kecamatan Koto Tangah Kota Padang." Journal Of Education Research And Evaluation (November).

7. Meril Valentine Manangkot, et al. 2016. "Pengaruh Senam Lansia Terhadap Keseimbangan Tubuh Pada Lansia Di Lingkungan Dajan Bingin Sading." Jurnal Keperawatan Community Of Publishing In Nursing (Coping) Ners (April): 24-27.

8. Ratnawati, Emmela. 2017. Keperawatan Komunitas. Yogyakarta: Pustaka Batu Press.

9. Rusmawan, Uus. 2019. Teknik Penulisan Tugas Akhir Dan Skripsi Pemograman. Jakarta: Pt Gramedia.

10.Supraba, N. P. 2016. Hubungan Aktivitas Sosial, Interaksi Sosial, Dan Fungsi Keluarga Dengan Kualitas Hidup Lanjut Usia Di Wilayah Kerja Puskesmas I Denpasar Utara Kota Denpasar. Tesis. Bali.

11.Susilo, W,. Limyat, Y,. \& Decky, G,. 2017. The Risk of Falling in Elderly Increased With Age Growth and Unaffected y Gender. Journal of Medicine and Health, 3.

12. Tabita Ma Windri, Angkit Kinasih, Thresia Pratiwi Elingsetyo Sanubari. 2019. "Pengaruh Aktivitas Fisik
Dengan Kualitas Hidup Lansia Hipertensi Di Panti Wredha Maria Sudarsih Ambarawa." Jurnal Mitra Pendidikan (Jmp Online) 3(11): 1444-51.

13.Wahyuni, Sri. 2019. "Systematic Review Metode Intervensi Pengetahuan Masyarakat Dalam Pengendalian Kasus Leptospirosis Di Wilayah Kota Semarang." Jurnal Kesehatan Masyarakat (E-Journal) 7(1): 211-20.

14.WHO. 2018. Ageing And Health. Jenewa.

http://www.who.int/news-room/fact-sh eets/detail/ageing-and-health.

15.Widianti, Anggriana, Tri \& Proverawati. 2010. Senam Kesehatan. Yogyakarta: Nuha Medika. 